\title{
ANALISIS KESULITAN YANG DIHADAPI OLEH GURU DAN PESERTA DIDIK SEKOLAH MENENGAH PERTAMA DALAM IMPLEMENTASI KURIKULUM 2013 PADA MATA PELAJARAN MATEMATIKA (Studi Kasus Eks-Karesidenan Madiun)
}

\author{
Ika Krisdiana $^{\text {1) }}$, Davi Apriandi ${ }^{2)}$, Reza Kusuma Setiansyah ${ }^{3)}$ \\ ${ }^{1}$ Pendidikan Matematika, FPMIPA IKIP PGRI Madiun \\ Email : ikakrisdiana56@gmail.com \\ ${ }^{2}$ Pendidikan Matematika, FPMIPA IKIP PGRI Madiun \\ Email: davi_apriandi@yahoo.com \\ ${ }^{3}$ Pendidikan Matematika, FPMIPA IKIP PGRI Madiun \\ Email: rezasetyansah@gmail.com
}

\begin{abstract}
Abstrak
Penelitian ini bertujuan untuk mengetahui kesulitan yang dialami guru dan peserta didik Sekolah Menengah Pertama (SMP) dalam implementasi kurikulum 2013 pada mata pelajaran matematika dan faktor-faktor yang menyebabkan kesulitan tersebut, serta untuk mengetahui solusi dalam mengatasi kesulitan guru dan peserta didik dalam implementasi kurikulum 2013 pada mata pelajaran matematika. Penelitian ini termasuk penelitian kualitatif. Populasi dalam penelitian ini adalah semua guru dan peserta didik Sekolah Menengah Pertama di Karesidenan Madiun. Subyek penelitian dipilih dengan menggunakan teknik purposive sample. Dipilih tiga Kabupaten/Kota dalam wilayah Karesidenan Madiun. Sekolah yang menjadi sampel penelitian ini adalah dua SMP dari setiap Kabupaten/Kota yang dipilih, dengan kriteria bahwa sekolah yang akan dijadikan sampel telah melaksanakan Kurikulum 2013. Pengumpulan data dilakukan dengan metode angket, observasi dan wawancara. Teknik analisis data dilakukan dengan analisis data kualitatif, yaitu reduksi data, penyajian data dan penarikan kesimpulan. Hasil dari penelitian ini adalah kesulitankesulitan yang dihadapi guru dalam mengimplementasikan kurikulum 2013 pada matapelajaran matematika, antara lain: (1) guru kurang memahami tujuan Kurikulum 2013 dan pendekatan saintifik, (2) penggunaan bahasa dalam buku teks sulit dipahami dan kurang efektif dalam meningkatkan proses pembelajaran, (3) guru kurang mampu melaksanakan proses pembelajaran yang menuju keterampilan aplikatif, (4) guru kurang mampu melakukan proses pembelajaran yang membuat peserta didik menjadi ingin melakukan pengamatan dan eksperimen, (5) guru kurang mampu melakukan proses pembelajaran yang menumbuhkan kreatifitas peserta didik. Sedangkan kesulitan-kesulitan yang dihadapi peserta didik dalam mengimplementasikan kurikulum 2013 pada matapelajaran matematika, antara lain: (1) peserta didik mengalami kesulitan dalam memahami isi, contoh-contoh dan bahasa dalam buku teks, (2) peserta didik jarang dilatih melakukan pengamatan dan percobaan, (3) dalam proses pembelajaran berlangsung guru jarang menggunakan teknologi informasi dalam proses belajar mengajar. Adapun faktor-faktor yang menyebabkan kesulitan tersebut adalah (1) kurangnya pelatihan atau workshop tentang kurikulum 2013, (2) kurangnya sarana dan prasarana dalam pembelajaran disekolah, (3) kurangnya pemahaman terhadap kompetensi inti dan kompetensi dasar, (4) materi dan contoh soal yang disajikan dalam buku teks sulit dipahami oleh siswa, (5) guru masih menerapkan pembelajaran konvensional, sehingga kurang menggali kemampuan siswa, (6) guru kurang kreatif dalam menerapkan model dan metode pembelajaran, (7) kemampuan guru dalam pemanfaatan teknologi, informasi dan teknologi masih lemah. Solusi yang ditawarkan untuk mengatasi kesulitan tersebut adalah: (1) perlu diadakan pelatihan/workshop tentang kurikulum 2013, (2) guru harus lebih banyak belajar dan membaca tentang implementasi kurikulum 2013, (3) guru harus lebih kretif dalam menerapkan model/metode pembelajaran yang berpusat pada siswa, (4) kemampuan guru dalam bidang teknologi, informasi dan komunikasi harus ditingkatkan dengan mengikuti workshop/pelatihan.
\end{abstract}

Kata Kunci: kesulitan guru dan peserta didik, implementasi kurikulum 2013 


\section{PENDAhuluan}

Penyelenggaraan

pendidikan

sebagaimana yang diamanatkan dalam Undang-undang Nomor 20 Tahun 2003 tentang Sistem Pendidikan Nasional diharapkan dapat mewujudkan proses berkembangnya kualitas pribadi peserta didik sebagai generasi penerus bangsa di masa depan, yang diyakini akan menjadi faktor determinan bagi tumbuh kembangnya bangsa dan negara Indonesia sepanjang zaman.

Pengembangan Kurikulum 2013 merupakan langkah lanjutan pengembangan Kurikulum Berbasis Kompetensi yang telah dirintis pada tahun 2004 dan KTSP 2006 yang mencakup kompetensi sikap, pengetahuan, dan keterampilan secara terpadu. KTSP masih dianggap belum sepenuhnya berbasis kompetensi sesuai dengan tuntutan fungsi dan tujuan pendidikan nasional, sehingga perlu pengembangan kurikulum baru yang mampu menutupi kelemahan-kelemahan dari kurikulum sebelumnya. Kurikulum 2013 dilandasi pemikiran tantangan masa depan yaitu tantangan abad ke 21 yang ditandai dengan abad ilmu pengetahuan,knowlwdgebased society dan kompetensi masa depan. Selain itu beberapa alasan perlunya pengembangan Kurikulum 2013 adalah: 1) Perubahan proses pembelajaran (dari siswa diberi tahu menjadi siswa mencari tahu) dan proses penilaian (dari berbasis output menjadi berbasis proses dan output) memerlukan penambahan jam pelajaran; 2)Kecenderungan banyak negara menambah jam pelajaran; dan 3)Perbandingan dengan negara-negara lain menunjukkan jam pelajaran di Indonesia dengan negara lain relatif lebih singkat.

Pemerintah lewat Kementerian Pendidikan dan Kebudayaan sudah melakukan uji publik guna mendapatkan tanggapan dari berbagai elemen masyarakat. Implementasi kurikulum 2013 berlaku bagi sekolah yang sudah akreditasi A maupun yang belum terakreditasi, sehingga bisa diketahui apa kelemahan di sekolah akreditasi dan apa kelemahan kurikulum di sekolah yang belum akreditasi. Untuk tahap awal, kurikulum 2013 diterapkan ke beberapa kelas, yakni sekolah dasar kelas 1 dan IV sedangkan untuk SMP dan SMA masing-masing kelas I.

Pada kenyataannya, prioritas sasaran implementasi Kurikulum 2013 ini adalah sekolah eks-RSBI dan sekolah yang terakreditasi A.. Mendikbud merilis ada 6.410 sekolah eks-RSBI dan berakreditasi A yang akan menjadi sasaran implementasi Kurikulum 2013. Masing-masing terdiri dari 2.598 SD, 1521 SMP, 1.270 SMA, dan 1.021 SMK. Sasaran prioritas implementasi Kurikulum 2013 semula akan dilakukan pada 132 ribu sekolah, kemudian berubah menjadi hanya $\quad 6.410 \quad$ sekolah. (http://www.radarcirebon.com/quo-vadiskurikulum-2013/).

Minimnya sosialisasi juga mengakibatkan rendahnya tingkat pemahaman guru terhadap Kurikulum 2013 ini. Berdasarkan hasil survei yang dilakukan Hotline Pendidikan Jawa Timur (Jatim) di Surabaya yang dilaksanakan September hingga Oktober 2013 dengan jumlah sasaran sekitar 240 guru SD dan SMP, guru-guru 
hanya sebatas memahami kurikulum, namun untuk membuat perencanaan dan penerapan di sekolah, mereka belum bisa menjalankan sesuai dengan harapan pemerintah (http://koran-sindo.com/node/342503). Hal ini berbanding lurus dengan apa yang dialami oleh guru-guru di Madiun. Berdasarkan hasil observasi kepada guru-guru khususnya guru matematika, ternyata masih banyak guru yang kebingungan dalam menerapkan kurikulum tersebut. Para guru masih belum paham tentang kompetensi inti dan kompetensi dasar, sehingga mereka kesulitan tentang bagaimana cara mengajar dan menilai. Pada kurikulum sebelumnya, guru lebih banyak memberikan materi di depan kelas, namun pada Kurikulum 2013 siswalah yang dituntut berperan aktif. Tak hanya guru, tapi peserta didik juga masih banyak yang bingung. Hal ini terlihat dari masih banyaknya peserta didik yang belum siap mengikuti pembelajaran dengan kurikulum 2013.

Dengan mengetahui kesulitan yang di alami guru dan peserta didik dapat dicari faktor-faktor yang menyebabkan kesulitan tersebut dan sekaligus dicari solusi untuk menyelesaikan permasalahan tersebut. Berdasarkan permasalahan di atas, akan dianalisis kesulitan yang dialami guru dan peserta dalam implementasi kurikulum 2013 dalam mata pelajaran matematika, faktorfaktor yang menyebabkan kesulitan tersebut dan sekaligus dicari solusi untuk menyelesaikan permasalahan tersebut.

\section{METODE PENELITIAN}

Jenis penelitian yang digunakan adalah penelitian kualitatif. Penelitian kualitatif menghasilkan data deskriptif berupa kata-kata tertulis atau lisan dari orang-orang dan perilaku yang dapat diamati. Menurut Lofland dalam Lexy J. Moleong (2007 : 157), sumber data utama dalam penelitian kualitatif ialah kata-kata, tindakan, selebihnya adalah data tambahan seperti dokumen dan lain-lain. Dalam penelitian ini, sumber data yang digunakan antara lain: (1) Kata-kata dan tindakan merupakan sumber data utama. Sumber data utama ini dicatat melalui catatan lapangan dan rekaman audio. Pencatatannya melalui observasi dan wawancara dengan subyek penelitian dan informan, (2) Sumber tertulis, dibagi atas sumber buku dan majalah ilmiah, sumber dari arsip, dokumen pribadi, dan dokumen resmi. Dalam penelitian ini yang digunakan adalah angket.

Populasi dalam penelitian ini adalah semua guru dan peserta didik Sekolah Menengah Pertama di Karesidenan Madiun. Subyek penelitian dipilih dengan menggunakan teknik purposive sample. Menurut Suharsimi Arikunto (2006: 139), purposive sample dilakukan dengan cara mengambil subyek bukan didasarkan strata, random atau daerah tetapi didasarkan atas adanya tujuan tertentu. Dipilih tiga Kabupaten/Kota dalam wilayah Karesidenan Madiun. Sekolah yang menjadi sampel penelitian ini adalah dua SMP dari setiap Kabupaten/Kota yang dipilih, dengan kriteria bahwa sekolah yang akan dijadikan sampel telah melaksanakan Kurikulum 2013, sehingga seluruhnya akan terdapat $3 \times 2=6$ SMP. Setiap SMP diwakili oleh 2 orang guru 
matematika dan 5 siswa. Sehingga terdapat 12 guru dan 30 siswa sebagai subjek penelitian.

Pengumpulan data dilakukan dengan angket, observasi dan wawancara. Setelah data terkumpul dilakukan analisis data yaitu data reduction (reduksi data), data display (penyajian data) dan conclusion drawing/verification (penarikan kesimpulan dan verifikasi).

\section{HASIL DAN PEMBAHASAN}

Karesidenan Madiun terdiri dari 5 Kabupaten/Kota, yaitu Kabupaten Madiun, Kabupaten Magetan, Kabupaten Ponorogo, Kabupaten Pacitan dan Kota Madiun. Dari Kabupaten/Kota di Karesidenan Madiun dipilih secara acak tiga Kabupaten/Kota sebagai tempat untuk penelitian dan terpilih Kabupaten Madiun, Kabupaten Magetan dan Kota Madiun. Dari tiga Kabupaten/Kota yang terpilih di ambil masing-masing dua Sekolah Menengah Pertama (SMP) secara acak dari beberapa sekolah yang telah melaksanakan Kurikulum 2013

Di Kabupaten Madiun terpilih dua sekolah yaitu SMPN 1 Dolopo dan SMPN 1 Geger, di Kab. Magetan terpilih SMPN 1 Kawedan dan SMPN 1 Karangrejo, Kota Madiun terpilih SMPN 2 Madiun dan SMPN 7 Madiun. Dari beberapa sekolah yang terpilih, diambil dua guru dan lima peserta didik yang telah melaksanakan Kurikulum 2013. Sehingga jumlah responden dalam penelitian ini sejumlah 12 orang guru dan 30 peserta didik.

Beberapa guru dan siswa yang telah dipilih, kemudian diberikan angket terkait implementasi kurikulum 2013 guna melihat respon dan mengetahui kesulitan yang dialami guru dan peserta didik setelah melaksanakan pembelajaran dengan kurikulum 2013.

Berikut hasil angket dari guru: Indikator angket guru dikatakan sulit jika lebih dari 3 orang guru menyatakan tidak/kurang paham/sulit. Dari hasil angket, kesulitan yang dialami oleh guru dalam mengimplementasikan kurikulum 2013 antara lain:

1. Guru kurang memahami tujuan Kurikulum 2013 dan pendekakatan saintifik.

Dalam pemahaman terhadap kurikulum 2013, guru mengalami kesulitan pada memahami tujuan kurikulum 2013. Lebih dari $40 \%$ guru merasa kurang paham terkait hal itu. Hal ini disebabkan karena kurang aktifnya guru dalam mencari informasi/referensi terkait kurikulum 2013. Selain itu, kurangnya pelatihan atau workshop yang diikuti, sehingga pemahaman dalam implementasi kurikulum 2013 masih kurang. Dalam pelaksanaannya, dengan diterapakannya kurikulum 2013 ini kesulitan lain yang dialami guru adalah dalam pemahaman pendekatan saintifik, padahal kurikulum 2013 menggunakan pendekatan saintifik dalam pembelajaran. Pendekatan saintifik diyakini sebagai titian emas perkembangan dan pengembangan sikap, keterampilan, dan pengetahuan peserta didik. Hal ini terjadi karena kurangnya guru dalam mencari referensi terkait pendekatan saintifik. Kesulitan lain yang dialami 
adalah kesulitan dalam memahami Kompetensi Inti dan Kompetensi Dasar.

2. Penggunaan bahasa dalam buku teks sulit dipahami dan kurang efektif dalam meningkatkan proses pembelajaran.

Buku teks mata pelajaran matematika materinya terlalu tinggi, tidak cocok untuk anak-anak yang baru lulus dari sekolah dasar. Berdasarkan daftar pustaka yang disajikan pada bagian akhir buku, buku teks matematika menggunakan buku-buku referensi untuk konsumsi mahasiswa Jurusan Matematika. Menurut para guru, contoh soal yang disajikan pun tidak berjenjang dari mudah ke sukar, namun langsung ke persoalan yang sukar dipahami oleh siswa. Bahkan, banyak soal latihan yang bobotnya setara dengan soal-soal untuk Olimpiade Sains Nasional (OSN). Materi yang sangat sukar bisa membuat anak-anak frustrasi sehingga tidak suka belajar matematika. Jika dibandingkan dengan buku teks mata pelajaran lain, buku teks matematika memiliki jumlah halaman paling banyak, sekitar 440 halaman, dan harus diselesaikan dalam waktu dua semester. Dalam buku teks matematika juga banyak dijumpai salah ketik, khususnya dalam penulisan simbol-simbol matematika.

3. Guru kurang mampu melaksanakan proses pembelajaran yang menuju keterampilan aplikatif.

Pembelajaran Kurikulum 2013 berubah dari pembelajaran verbalisme menuju keterampilan aplikatif, yang pada waktu lalu pembelajaran berlangsung ceramah.
Segala sesuatu diungkapkan dalam bentuk lisan guru, fakta disajikan dalam bentuk informasi verbal, sekarang siswa harus lihat faktanya, gambarnya, videonya, diagaramnya, teksnya yang membuat siswa melihat, meraba, merasa dengan panca indranya. Siswa belajar tidak hanya dengan mendengar, namun dengan menggunakan panca indra lainnya. Berdasarkan wawancara, guru kesulitan dalam menyusun/membangun proses pembelajaran yang lebih menekankan pada ketrampilan siswa dan dalam proses pembelajaran pun guru masih mendominasi.

4. Guru kurang mampu melakukan proses pembelajaran yang membuat peserta didik menjadi ingin melakukan pengamatan dan eksperimen.

Di dalam proses belajar mengajar, guru harus memiliki strategi, agar siswa dapat belajar secara efektif dan efisien, mengena pada tujuan yang diharapkan. Salah satu langkah untuk memiliki strategi itu ialah harus menguasai teknik-teknik penyajian, atau biasanya disebut metode mengajar. Teknik penyajian pelajaran adalah suatu pengetahuan tentang cara-cara mengajar yang dipergunakan oleh guru atau instruktur. Pengertian lain ialah sebagai teknik penyajian yang dikuasai guru untuk mengajar atau menyajikan bahan pelajaran kepada siswa di dalam kelas, agar pelajaran tersebut dapat ditangkap, dipahami dan digunakan oleh siswa dengan baik. Salah satu teknik penyajian pelajaran yang digunakan dalam penelitian ini adalah 
teknik penyajian pelajaran eksperimen atau disebut juga dengan metode eksperimen. Dengan adanya kemajuan teknologi dan ilmu pengetahuan maka segala sesuatu memerlukan eksperimentasi. Begitu juga dalam cara mengajar guru di kelas digunakan teknik eksperimen, yaitu salah satu cara mengajar di mana siswa melakukan suatu percobaan tentang suatu hal, mengamati prosesnya serta menuliskan hasil percobaannya, kemudian hasil pengamatan itu disampaikan ke kelas dan dievaluasi oleh guru.

Berdasarkan hasil angket, lebih dari $50 \%$ guru matematika kesulitan dalam merancang pembelajaran yang menekankan pada pengamatan dan eksperimen. Berdasarkan wawancara, hal ini terjadi memang dalam proses pembelajaran metode yang sering digunakan adalah metode ceramah, sehingga mereka tidak melibatkan siswa secara aktif dalam pembelajaran. Selain itu meraka menganggap materi matematika sulit dipahami apabila diterapkan dengan metode eksperimen.

5. Guru kurang mampu melakukan proses pembelajaran yang menumbuhkan kreatifitas peserta didik.

Pembelajaran kreatif dalam proses pembelajaran mampu membuat siswa mengembangkan kreativitasnya. Itu berarti bahwa pembelajaran kreatif itu membuat siswa aktif membangkitkan kreativitasnya sendiri. Mengembangkan kreativitas siswa dalam pembelajaran berarti mengembangkan kompetensi memenuhi standar proses atau produk belajar yang selalu terbarukan. Di sini diperlukan strategi agar siswa mampu menghasilkan gagasan yang baru, cara baru, disain baru, model baru atau sesuatu yang lebih baik daripada yang sudah ada sebelumnya.

Segala sesuatu yang baru itu muncul dengan pemicu, di antaranya, karena tumbuh dari informasi yang baru, penemuan baru, teknologi baru, strategi belajar yang baru yang lebih variatif, sistem kolaborasi dan kompetisi yang baru, eksplorasi ke wilayah sumber informasi baru, menjelajah forum komunikasi baru, mengembangkan stategi penilaian yang baru yang lebih variatif.

Berdasarkan wawancara dengan guru,dalam proses pembelajaran guru lebih banyak menggunakan metode yang sama dalam hal mengajar, dengan alasan karena sudah terbiasa jadi lebih mudah dalam menyampaikan materi. Padahal untuk menumbuhkan kreatifitas siswa, salah satu pemicunya adalah strategi/metode pembelajaran guru yang variatif. Jadi diharapkan guru mempersiapkan perangkat pembelajaran yang mampu mengembangkan kreativitas siswa.

Hasil angket dari siswa setelah mengikuti pembelajaran dengan kurikulum 2013 adalah sebagai berikut: Indikator angket peserta didik dikatakan sulit jika lebih dari 5 orang peserta didik menyatakan tidak/kurang paham/sulit. Dari hasil angket, kesulitan yang dialami oleh peserta didik dalam mengimplementasikan kurikulum 2013 antara lain: 
1. Peserta didik mengalami kesulitan dalam memahami isi, contoh-contoh dan bahasa dalam buku teks

Buku teks yang baik adalah buku pelajaran yang dapat membantu siswa belajar. Buku teks bukan hanya merupakan buku yang dibuka atau dibaca pada saat pembelajaran di kelas, buku teks merupakan bahan acuan pembelajaran dan sebagai sarana untuk membantu belajar siswa, juga untuk membantu siswa memahami materi yang akan mereka pelajari dengan membaca dan memahaminya. Tetapi pada kenyataanya banyak siswa mengalami kesulitan dalam memahami isi dari buku teks. Dalam buku teks mata pelajaran matematika kurikulum 2013 ini materinya terlalu tinggi, kurang cocok untuk anak-anak yang baru lulus dari sekolah dasar. Bahkan, banyak soal latihan yang bobotnya setara dengan soal-soal untuk Olimpiade Sains Nasional (OSN). Materi yang sangat sukar bisa membuat anak-anak frustrasi sehingga tidak suka belajar matematika. Dalam buku teks matematika juga banyak dijumpai salah ketik, khususnya dalam penulisan simbolsimbol matematika. Hal ini lah yang menjadi alasan, kenapa siswa kesulitan dalam memahami materi dari buku teks

2. Peserta didik jarang dilatih melakukan pengamatan dan percobaan.

Dalam pembelajaran matematika, sebagian besar guru masih menggunakan metode ceramah dalam menjelaskan materi ke siswa nya. Hal ini tidak sesuai dengan hakikat dari kurikulum 2013 dimana pembelajaran harus berpusat pada siswa, dengan proses pembelajaran semacam itu,siswa jarang dilibatkan dalam kegiatan pengamatan dan percobaan.

3. Dalam proses pembelajaran berlangsung guru jarang menggunakan teknologi informasi dalam proses belajar mengajar.

Fakta yang terjadi di lapangan, siswa kurang menyukai pelajaran matematika Hal ini selain dikarenakan matematika dianggap sebagai pelajaran yang sulit dipahami, selain itu juga karena pembelajaran matematika disajikan dalam bentuk pembelajaran yang konvensional dan kurang melibatkan siswa dalam kegiatan belajar mengajar sehingga siswa cenderung pasif selama pembelajaran. Selain itu, dalam pembelajaran guru jarang menggunakan media pembelajaran sehingga pembelajaran bersifat abstrak, apalagi media berbasis teknologi informasi dan komunikasi (TIK). Dalam kurikulum 2013, keharusan guru dalam mendorong dan mendukung siswa kearah kreatif pemanfaatan TIK mutlak dilaksanakan. Untuk itu peranan guru sangat dibutuhkan demi keseimbangan penguasaan dan pengemasan informasi yang bakal dihadapkan dan disajikan kepada siswanya. Karena ada kemungkinanan siswa telah memahami lebih jauh satu persoalan dari pada gurunya. Kondisi guru sebagaian besar masih belum optimal, bahkan masih banyak yang belum dapat memanfaatkan kemajuan TIK atau dengan perkataan lain masih gagap, kondisi ini perlu dicari penyebabnya dan solusi yang terbaik, 
khususnya bagi para penentu kebijakan pendidikan.

\section{KESIMPULAN DAN SARAN}

\section{Kesimpulan}

Berdasarkan hasil penelitian dan pembahasan maka dapat diambil kesimpulan sebagai berikut :

1. Dari hasil angket implementasi kurikulum 2013 dan wawancara terhadap guru dan peserta didik, kesulitan yang dihadapi oleh guru dan peserta didik adalah sebagai berikut:

a. Kesulitan yang dihadapi oleh guru Sekolah Menengah Pertama dalam mengimplementasikan kurikulum 2013 pada matapelajaran matematika:

1) guru kurang memahami tujuan Kurikulum 2013 dan pendekakatn saintifik

2) penggunaan bahasa dalam buku teks sulit dipahami dan kurang efektif dalam meningkatkan proses pembelajaran,

3) guru kurang mampu melaksanakan proses pembelajaran yang menuju keterampilan aplikatif,

4) guru kurang mampu melakukan proses pembelajaran yang membuat peserta didik menjadi ingin melakukan pengamatan dan eksperimen

5) guru kurang mampu melakukan proses pembelajaran yang menumbuhkan kreatifitas peserta didik b. Kesulitan yang dihadapi oleh peserta didik Sekolah Menengah Pertama dalam mengimplementasikan kurikulum 2013 pada matapelajaran matematika:

1) peserta didik mengalami kesulitan dalam memahami isi, contoh-contoh dan bahasa dalam buku teks

2) peserta didik jarang dilatih melakukan pengamatan dan percobaan

3) dalam proses pembelajaran berlangsung guru jarang menggunakan teknologi informasi dalam proses belajar mengajar.

2. Faktor-faktor yang menyebabkan kesulitan guru dan peserta didik Sekolah Menengah Pertama dalam implementasi kurikulum 2013 pada mata pelajaran matematika sebagai berikut:

a. Kurangnya pelatihan atau workshop tentang dberlakukannya kurikulum 2013

b. Kurangnya sarana dan prasarana dalam pembelajaran disekolah.

c. Kurangnya pemahaman terhadap kompetensi inti dan kompetensi dasar tiap sub pokok bahasan dalam penerapan sehari-hari.

d. Materi dan contoh soal yang disajikan dalam buku teks tidak berjenjang dari mudah ke sukar, namun langsung ke persoalan yang sukar dipahami oleh siswa

e. Keanekaragaman kemampuan siswa, daya imajinasi, kreatif, pengetahuan sikap/perilaku terhadap mata pelajaran berbeda apabila tugas dasar kelas VII 
dituntut keuletan, ketelitian dan kesabaran tenaga pendidik.

f. Guru masih menerapkan pembelajaran konvensional, sehingga kurang menggali kemampuan siswa.

g. Guru kurang kreatif dalam menerapkan model dan metode pembelajaran.

h. Kemampuan guru dalam pemanfaatan teknologi, informasi dan teknologi masih lemah.

3. Solusi dalam mengatasi kesulitan guru dan peserta didik dalam dalam implementasi kurikulum 2013 pada mata pelajaran matematika sebagai berikut:

a. Perlu diadakan pelatihan/workshop tentang kurikulum 2013.

b. Guru harus lebih banyak belajar dan membaca tenatang implementasi kurikulum 2013

c. Guru harus lebih kreatif dalam menerapkan model/metode pembelajaran yang berpusat pada siswa

d. Kemampuan guru dalam bidang teknologi, informasi dan komunikasi harus ditingkatkan dengan mengikuti workshop/pelatihan.

\section{Saran}

Berdasarkan kesimpulan seperti yang telah disebutkan, maka peneliti menyarankan hal-hal sebagai berikut:

1. Dinas Pendidikan atau lembaga pendidikan terkait harus sering mangadakan pelatihan/workshop kurikulum 2013 bagi tenaga pendidikan dan tenaga kependidikan.
2. Dinas Pendidikan atau lembaga pendidikan harus mendukung sarana dan prasarana, fasilitas, dan perangkat pendukung pemanfaatan TIK di sekolah-sekolah

3. Guru sebagai tenaga pendidik harus lebih giat belajar untuk memperbaiki kualitas pendidikan Indonesia.

\section{DAFTAR PUSTAKA}

Arief Ardliyanto. Guru Kesulitan Terapkan Kurikulum 2013. sindo.com/node/342503. Diakses pada 3 Desember 2013

Budiyono. 2003. Metodologi Penelitian

Pendidikan. Surakarta : UNS Press

Fahrus Zaman Fadhly. Quo Vadis Kurikulum 2013.

http://www.radarcirebon.com/quovadis-kurikulum-2013/. Diakses pada 2 Desember 2013

Kementerian Pendidikan dan Kebudayaan. 2013. Pedoman Pelatihan Implementasi Kurikulum 2013. Jakarta: Badan Pengembangan Sumber Daya Manusia Pendidikan dan Kebudayaan dan Penjaminan Mutu Pendidikan.

Lexy J. Moleong. 2007. Metodologi Penelitian Kualitatif. Bandung : PT Remaja Rosdakarya.

Sugiyono. 2011. Metode Penelitian Pendidikan. Bandung: Alfabeta.

Suharsimi Arikunto. 2002. Dasar-Dasar Evaluasi Pendidikan. Jakarta: Bumi Aksara. 
2006. Prosedur

Penelitian Suatu Pendekatan Praktek.

Jakarta : PT Rineka Cipta.

Tatang Sunendar. Kerangka dan Struktur

Kurikulum 2013.

http://www.lpmpjabar.go.id/sites/defaul

t/files/kerangka\%20dan\%20struktur\%2

0kurikulum\%202013.doc. Diakses pada

4 Desember 2013.

Undang-undang Republik Indonesia Nomor

20 tahun 2003. Sistem Pendidikan

Nasional. Jakarta: CV. Eko Jaya. 